\title{
THE UNDERSIDE OF ARABIC PANEGYRIC: IBN QUZMĀN'S (UNFINISHED?) «ZAJAL NO. 84»1
}

JAMES T. MONRoE

University of California, Berkeley

\section{INTRODUCTION}

In the last ode he composed, al-Mutanabbi (915-965 A.D.), that prince of Arab poets, addressed his patron, the Sultan 'Adud al-Dawla (936-983), in the following terms:

$\begin{array}{ll}\text { wa-kam țaribi l-masāmi'i laysa yadrī } & \text { 'a ya jabu min tanā 'î 'am 'ulā-kā } \\ \text { wa-dāka n-našru 'irdú-ka kāna miskan } & \text { wa-hādā š-ši'ru fihri wa-l-madākā }\end{array}$

And how many a hearer will rejoice, not knowing whether to marvel at my praise or your sublimity.

That sweet odour, your reputation, is musk, and [this] poetry my pestle and pounding stone ${ }^{2}$.

With these words, al-Mutanabbī was expressing, in his own inimitable way, an ancient and widespread assumption lying at the very heart of praise poetry: the poet, in his function as encomiast, places himself on an equal footing with the patron. This is so, because the praises of an inferior would carry little weight with a superior, and would even be interpreted as unconvincing by the public at large. Furthermore, while the ruler is celebrated as a model of courage, nobility, piety, and generosity, and is thus depicted as a supreme example of the values to which society traditionally adheres, he can only be directly admired by the limited number of persons

1 The original version of this study was presented as a paper read at Harvard University, in April, 1989, before the Departments of Comparative Literature, Romance, and Near Eastern Languages.

2 Dìwän al-Mutanabbī, With the Commentary by Abì l-Hasan 'Alì ibn Ahmad alWāhidì al-Naisabūrī (Died 468 A.H.), ed. Friederich Dieterici, Berlin: no publ., 1862, 804, 11. 30-31. See, too, A. J. Arberry (ed. and trans.), Poems of al-Mutanabbi, Cambridge, 1967, 144-145, 11. 30-31. Arberry, whose translation I otherwise adopt, reads wadāka š-ši rru ('and that poetry'). 
forming part of his immediate entourage. Since praise poetry normally emanates from within an exclusive and aristocratic circle, the ruler requires the professional services of a poet, whose function it will be to broadcast the royal virtues to the generality of mankind. Fourteen centuries before al-Mutanabbī, Pindar (ca 522-ca 442 B.C.) had made this clear:

\author{
... taì megálai gàr 'alkaì \\ skóton polùn húmnōn 'échonti deómenai \\ 'érgois dè kaloîs 'ésoptron 'ísamen heni sùn trópō \\ 'ei Mnāmosúnas hékāti liparámpukos \\ heúrētai 'ápoina móchthōn klutaîs 'epéōn 'aoidaîs
}

... even great deeds of prowess remain hidden in deep gloom if they lack song, yet for noble actions we can hold up a mirror in only one way: if, with the help of brightly-crowned Memory, a reward for hardship is found in the glorious singing of poetry ${ }^{3}$.

Along with panegyrists from other pagan cultures ranging broadly in time and place, Pindar was especially concerned with the ability of poetry to provide the only means of immortality available to man: worldly renown after death:

... 'eúthūn' 'epì toûton, 'áge, Moîsa,

'oûron 'epéōn

'eukléa. paroichoménōn gàr 'anérōn

'aoidaì

kaì lógoi tà kalà sphin 'érg' 'ekómisan.

... come, Muse, guide to this [patron], a glorious breeze of poetry, for when men have passed away, songs and tales preserve their glorious deeds for them ${ }^{4}$.

Such sentiments bear close resemblance to the following lines of modern Zulu praise poetry:

People will die, but their praises [izibongo] remain;

These will remain to weep for them in their deserted homes 5 .

3 Bowra, C. M. (ed.), Pindari Carmina cum Fragmentis, 2d ed., Oxford, 1947 (reprint: 1968), Nemean Ode VII, ll. 13-17 (translation mine).

4 Bowra, C. M. (ed.), Pindari Carmina, Nemean Ode VI, 11. 28-30 (translation mine). 34.

5 Opland, J., Anglo-Saxon Oral Poetry: A Study of the Traditions, New Haven, 1980, 
Because the religion of Islam offered an afterlife of wide-awake consciousness to its followers, in contrast to the Lethe-induced stupor that awaited the Ancient Greeks in the realm of Hades, Muslim panegyrists were less concerned than Pindar with the immortalizing function of praise poetry. Instead, they tended to concentrate on poetry's ability to spread the patron's fame during his own lifetime, and among his contemporaries. All the same, whether before or after death, both in the Islamic and the Greek traditions, the patron needed the skill of the poet to make his virtues known to this world. Conversely, being a professional who earns his livelihood from praising patrons, the poet cannot dispense with the latter. Poet and patron thus constitute a society for mutual admiration anchored in enlightened self-interest. According to the Persian poet, Hāfiz (ca 1320-ca 1390).

The poet exalts your noble deeds to the skies; do not begrudge him his stipend and travelling provisions.

Since you seek good repute, let me say this: do not begrudge silver and gold as the price of discourse ${ }^{6}$.

Pindar had long preceded this sentiment when he sang:

'ei dé moi ploûton theòs habròn 'oréxai,

'elpíd' 'échō kléos heurésthai ken hupsēlòn prósō.

But if God were to give me magnificent wealth, I would entertain hope of finding lofty fame hereafter ${ }^{7}$.

Several scholars who have studied manifestations of the panegyric genre in various traditions, have noted its essentially ritualistic character. According to such scholars, the solemn recitation of praise poems at court represents a public and collective reaffirmation of loyalty to the ruler, during the course of which he is simultaneously being reminded of the ideals to which he is expected to adhere. Even the reward made to the encomiast has ritual significance, insofar as it displays royal authority in its role as fountainhead of all abundance and prosperity to be

6 Hāfiz, Dìvān, ed. M. Qazvīnī and Wāsim Ġanī, Tehran, 1941, no. 247. Trans. Meisami, J., Medieval Persian Court Poetry, Princeton, 1987, 45. ne)

7 Bowra, C. M. (ed.), Pindari Carmina, Pythian Ode III, ll. 110-111 (translation mi- 
found in the realm ${ }^{8}$. Such poetry is thus didactic and moral, insofar as it holds up a model of proper conduct for public admiration. Hence, "its ultimate goal [is] the stimulation of virtue" 9 .

Modern man, if he adheres to ideals of democratic equality, has difficulties in identifying with, or relating to, an essentially aristocratic relationship in which one individual ritually praises another, unless the latter is dead or has asked for a letter of recommendation. As a result, the panegyrical genre has declined from its former privileged status, while panegyrics of the past are not understood or appreciated in the modern world. Such an attitude is particularly unfortunate with respect to Arabic literature, in which panegyric constitutes the bulk of pre-modern poetry. Yet we experience no unease, today, when singing hymns in praise of God. These are, after all, panegyrics, albeit of a special kind. In order to understand the development of the genre, we might, therefore, imagine an earlier stage, during which kings were still considered divine, and in which their panegyrists must have been viewed as offering hymns of praise to a divine being ${ }^{10}$. Seen from this perspective, the praise-poet is closely related to the prophet: if the former is a mouthpiece for a divine ruler, the latter is a spokesman for a god. This may

\footnotetext{
8 See Sperl, S., "Islamic Kingship and Arabic Panegyric Poetry in the Early 9th Century", Journal of Arabic Literature, 8 (1977), 20-35, at p. 34. See, too; Bowra, C. M., Pindar, Oxford, 1964; Bundy, E. L., Studia Pindarica, Berkeley, 1986; Caerwyn Williams, J. E., "The Court Poet in Medieval Ireland", Proceedings of the British Academy, 57 (1971), 85-135; Dumézil, G., Servius et la Fortune: Essai sur la fonction sociale de Louange et de Blâme et sur les éléments indo-européens du cens romain ${ }^{2}$, Paris, 1943; Finnegan, R. H., Oral Literature in Africa, Oxford, 1970; Oral Poetry: Its Nature, Significance, and Social Context, Cambridge, 1977; Frank, R. (ed.), Old Norse Court Poetry: The Drottkvaett Stan$z a$, Ithaca, New York, 1978; Hallberg, P., Old Icelandic Poetry: Eddic Lay and Skaldic Verse, trans. P. S. and S. Lindgrenson, Lincoln, 1962; Hardison Jr., O. B., The Enduring Monument: A Study of the Idea of Praise in Renaissance Literary Theory and Practice, Chapel Hill, 1962; Hollander, L. M., The Skalds: A Selection of their Poems, with Introduction and Notes, Princeton, 1945; Jacobi, R., Studien zur Poetik der altarabischen Qaside, Wiesbaden, 1971; Javitch, D., Poetry and Courtliness in Renaissance England, Princeton, 1978; Meisami, "The Poetry of Praise: The Qasidah and its Uses", Medieval Persian Court Poetry, 40, 76; Nagy, G., The Best of the Achaeans: Concepts of the Hero in Archaic Greek Poetry, Baltimore, 1979; "Ancient Greek Epic and Praise Poetry: Some Typological Considerations", Foley, J. M. (ed.), Oral Tradition in Literature: Interpretation in Context, Columbia, 1986, 89-102; Norwood, G., Pindar, Berkeley, 1945; Opland, Anglo-Saxon Oral Poetry, 19-27; Vail L., and White, L., Power and the Praise Poem: Southern African Voices in History, Charlottesville, 1991.

9 Meisami, Medieval Persian Court Poetry, 46.

10 See, for example, the cycle of hymns to the Middle Kingdom Pharaoh, Sesostris III, in Lichtheim, M., Ancient Egyptian Literature: A Book of Readings (3 vols.), Berkeley: 1975-1980, vol. I, 198-201.
} 
have been one of the reasons why the inhabitants of Mekka thought that Muhammad was a poet instead of a divinely inspired prophet 11 .

In order to be convincing, the strategies of praise poetry must leave the impression that the seemingly limitless affection the poet expresses for his patron is sincere. In a situation where a monetary reward changed hands, this was, no doubt, often not the case. Nevertheless, in a public ritual, the purpose of which was to reaffirm traditional values by extolling the majesty of the sovereign, the private sincerity of the poet is not crucial to the poem's effectiveness. Hence medieval rhetoricians, such as Qudāma ibn Ja'far (converted to Islam between 902 and 906), could declare:

It must also be submitted that if a poet contradicts himself in two poems or words, by describing an object favorably [in one place], while condemning it elsewhere, in an eloquent and beautiful way, this is not to be held against him, nor to be considered reprehensible on his part, if he succeeds both in praising and blaming. On the contrary: in my opinion, the above reveals the ability of the poet in his art, along whith his mastery over it 12 .

Because the medieval Arab rhetorician was chiefly interested in poetic materials (e.g., signifier, signified, meter, and rhyme) rather than in structure, he left the panegyrical genre in a peculiar moral limbo. Of this situation, certain Arab authors were, nonetheless, keenly aware. Among them was Badī‘ al-Zamān al-Hamadānī (967-1008), the inventor of the picaresque Arabic genre known as the maqäma. In his «Maqāma of Poesie», Badī‘ al-Zamān has his anti-hero, Abū l-Fatḥ al-Iskandarī, express his opinions about the great poets of Arabic literature. Beginning with the pre-Islamic figure of Imru' al-Qays, the speaker approves of that poet above all others because "he did not compose poetry for gain, nor speak eloquently from covetousness and, therefore, he was superior to him whose tongue was loosened designingly, and whose fingers were foraging for a prize» ${ }^{13}$. In al-Hamadāni’s eyes, the potential for venality is, therefore, ever present in the panegyric. Should such venality become apparent, it would seriously undermine the poet's credibility, thus rendering the ritual meaningless. What happens, howe-

11 See Qur'ān, 21:5; 37:36; 52:30; 69:41.

12 Kitāb Naqd al-ši ${ }^{r}$, ed. '̇̃sà Mīhāẩ Sābā, Harīṣa, Beirut, 1958, 14-15 (my translation).

13 Maqāmāt Abì l-Fadl Badī' al-Zamān al-Hamadānīi, ed. Muhammad 'Abduh, 2d ed., Beirut, 1908, 10-11; trans. W. J. Prendergast, The Maqámát of Badi" al-Zamán al-Hamadháni, London, 1915 (reprint: 1973), 27. For a literary analysis of this maqäma, see Monroe, J. T., The Art of Badī' az-Zamän al-Hamadhäni as Picaresque Narrative, Papers of the Center for Arab and Middle East Studies 2, Beirut, 1983, 26-31. 
ver, when panegyric is torn from its royal and/or religious context, and used to praise ordinary individuals? Will its ritual character continue to be effective? This is precisely the dilemma that arose in al-Andalus in the first half of the twelfth century. At that time, the Almoravid dynasty, which was of Berber extraction, had a shaky knowledge of written Arabic, and little interest in the refinements of literature, was ruling over a population including highly sophisticated Andalusī poets who had, until recently, been looked upon with favor at the innumerable courts of the now deposed mulük at țtawäiff. Such poets now saw their services scorned at court, hence they resorted to the patronage of private citizens and local officials. The greatest Andalusi poet among them, and one of the most complex of all medieval poets, was Ibn Quzmān (d. 1160).

It cannot fail to strike the attentive reader of Ibn Quzmān's Diwān that the overwhelming majority of the 149 zajals it preserves belong to the panegyrical genre. They are largely songs addressed to non-royal Andalusi notables. Few of the poems are addressed to Almoravid rulers, and when they are, we usually find them to be short and unenthusiastic compositions ${ }^{14}$. How, then, does a panegyrical poet handle the genre, when it is divorced from its traditionally royal environment, and cultivated, in order to earn a living, among persons who are that poet's social peers? To this challenge, Ibn Quzmān provides one response which I wish to explore in the course of this essay. Let me do so by concentrating on a single poem; Zajal No. 84, which is not only fraught with philological and literary problems, but which is typical of how Ibn Quzmān deals with the genre.

The poem is a consummate piece of poetic deviousness, for which E. García Gómez has provided the following thematic summary:

The first six introductory strophes are the least good ones. The situation is -and here, in strophe 7, matters begin to get livelier- that as usual, [the poet] has no money ${ }^{15}$. A frivolous female neighbor, who visits him

14 See, for example, Zajal No. 47, which is only four strophes long, in the last of which the poet explicitly declares "I've said my piece, and clear / Lie my excuses. / Song's end draws nigh; my close, / This verse produces! / You're Almoravids all; / I know your uses: / Verbosity you loathe, / And words repeated!» Arabic text, Corriente, F., Gramática, métrica y texto del Cancionero hispanoárabe de Aban Quzmán, Madrid, 1980, 322 (translation mine).

${ }_{15}$ However, the colloquial Hispano-Arabic sentence lam tahușșu qițä does not mean "he has no money" as García Gómez interpreted, but "he lacks no money». See R. Dozy, Supplément aux dictionnaires arabes, Leiden, 19673, vol. I, 375a. In this context, the poet is not talking about his own lack of money, but about the fact that even independently wealthy persons are subject to the vicissitudes of Fate. 
on occasion, enters the poet's house playing the castanets, and tells Ibn Quzmān his fortune. It turns out that the only hope of obtaining money lies in appealing to a certain Abū l-'Alā' who lives out of town. The poet promises the fortuneteller generous gifts (strophe 15), and prepares to depart, very early in the morning. But a muleteer, at daybreak, gives him an epileptic mule that cannot travel and, while muleteer and poet argue, the mule train departs. Here the zajal, in which there are several words and phrases in Romance, is interrupted.

Curiously, I have never seen it pointed out that this zajal is obviously missing its end. We do not know what direction it took, although it is certain that it must have concluded with a panegyric of somebody, probably the Abū l-'Alā' mentioned earlier ${ }^{16}$.

Following García Gómez's lead, Federico Corriente describes the poem as an incomplete zajal that must have ended with a panegyric to Abū l'Alā', who was probably the vizier and jurist Abū l'Alā' ibn Zuhr mentioned in the Introduction [to the Diwazn], and who is addressed in zajals 9 and $86 . . .1{ }^{17}$. Both my predecessors are thus in agreement that the poem was intended as a panegyric, of which the final, actual panegyrical section has been lost. Let me proceed to argue that the matter may not be quite that clear cut.

In order to do so, I have found it necessary to provide my own edition and translation of the poem. In preparing this text, I have not hesitated to choose between readings proposed by García Gómez and Corriente, when these two scholars are in disagreement. Occasionally, I have introduced (suggested) improvements based on my own understanding of the manuscript ${ }^{18}$. Since space does not allow for a full justification of the text, anyone with a further interest in its philological niceties is invited to compare my version of it with those found in García Gómez's and Corriente's respective editions and translations ${ }^{19}$.

16 Todo Ben Quzmān, Madrid, 1972, vol. I, 418-419 (translation mine).

17 Ibn Quzmãn: El Cancionero hispanoárabe, Madrid, 1984, 343, n. 1 to Zajal No. 84 (translation mine). Abū l'Alā' ibn Zuhr was the father of the famous physician Avenzoar (ibid., 310, n. 28; Encyclopaedia of Islam², vol. III, 976-977). 90.

18 Facsimile ed. David de Gunzburg, Le Divan d'Ibn Guzman, Berlin, 1896, fols. 88-

19 Corriente's Spanish translation (El Cancionero hispanoárabe, 196-199) does not always reflect his edition of the Arabic text in (Gramática, métrica y texto, 538-547) because, between the publication of the two works, his understanding of the text improved considerably. See, too, his recent re-edition: El Cancionero Hispano-Arabe de Aban Quzmán de Córdoba (m. 555/1160) «Ișäbat al-Agräd fí dikr al-áräạd», Cairo, 1995, 256-26. 


\section{Arabic TeXt and Translation}

0. fi ḍamānī 'in tu'țà 'al-hiyār lam tarā mā ra'ayt min al-asfār

1. qad maḍa 'umrī f-al-maḍī wa-r-rujū' f-ahlà mā nahbațu tarā-ni țulü‘ fa-'idā rayt haris fa-huwa mamnū innamā las ma aḍ-ḍarūra hntiyār

2. kān bi-wuddī law kān li-ra'yi sabịl allā națlub bi-d̄ā l-madīna badī las yarā had murādu 'illā qalīl wa-'alà hāl tașarruf al-aqdār

3. tadri laš kān hurūiji min dā l-balad tamm hubayyar iyyāk taqūlu li-ḥad qad badā lī wa-qad nasaytu ba'ad wa-kadā qaṭ naqul lak al-ahbār

4. w-in jahạadtu yaqa' bi-hạāl sū 'adab ba-llah law kān hadā l-hadìt min dahab tadri kaf kān wa-kaf jarà dēā s-sabab sa-naqul lak tamna' -ni dāb a‘dār

5. lam nasaddaq bi-hajri ba'di wișāl dābi yă hִi 'al-ḥaqqi mā kān yuqāl gafar allah li-man wa'ad tumma hāl kunta 'at li wafi w-anā gàddār

6. da'-ni min dā fa-las nuhun sibyān jur wa-'ansif qad kān ba'ad mā kān țūl hayāầi las nadkuruh bi-lisān yalzam al-wāhid an yahāâ al-'ār

7. 'āš al-insān wa-lam tahussu qitāa wa-baqà la-z-zaman yaqum wa-yaqa' 'alà 'ilm-ak las bi-hi tāqah dirāa innamā-hu kamā tarà 'inhidār

8. tamma qisșah kānat li fäl-an 'ajỉb fa-jarà lì wa-[llahi] jary-an garỉb ma' murayya taskun juwārī qarib kat-taji-nî fi-šān huwwayyaj la-d-dār

9. fa-kamā kān 'ašiyyah wa-qad jāt bi-qușay[b]ah fi yaddi-hã wa-badāt an taharrak wa-tadrab aš-šizāt wa-n-nusayyāt taḥibbu dẹa l-aḥbār
I guarantee that, even if you were given cucumbers [or: 'a choice'],

You wold not see the travels I have seen.

My life has been spent in coming and going;

As soon as I fall, you'll see me rise again;

Whenever I see something desirable, it is forbidden

Under compulsion, there is no freedom of choice.

If I could have had my way, I would have preferred Not to move from this city,

But rarely does one get what one wants,

And [always] at the discretion of Fate.

Do you know why I left this town?

Therein lies a tale! See that you tell it to no one!

I've changed my mind and forgotten all about it.

On second thought, I'll tell you the tale after all.

If I refused, it would be unmannerly.

By God, if only this story were worth gold!

Do you know what happened; the cause of it all?

I'll tell you; you forbid my excuses.

I don't believe in avoidance after a love-union.

It is my custom, friend, to tell the truth, whatever it may be. God forgive him who makes a promise, then breaks it! Since you have been faithful to me, can I be faithless?

Spare me this, for we are no longer children; Whether you're fair or unfair to me, the past is the past; As long as I live, I won't mention it in any tongue, For one must fear disgrace.

A man may live with no lack of money, Yet end up rising and falling at the whim of Fate. As you know, one has no power

It's all downhill, as you can see.

On this point, $\mathrm{I}$ had an amazing omen, For a remarkable thing happened to me With a little female living nearby, in my neighborhood, Who used to come to my home to care for my needs.

It was evening, and she had come

With a small flute in her hand, and began

To vibrate, and to beat the castanets,

For little females enjoy doing that sort of thing. 
10. anā 'ay kunt nazartu mā ta'mal min fulān sīr w-abṣir fulān muqbal wa-l-hubüb kulli marrah tatbaddal aš naqul lak YĀ ${ }^{20}$ lam na'ud [h]]ummär ${ }^{21}$

11. quitu la ba-llah anzur tamm aš yakūn nazarat kaff[ayya] wa-qālat lī[B]ŌN 22 FÄTTAŠ ALBAŠ 23 narāk bi-ḥāl al-quțūn [aww]adā l-jāh [EŠ DE] NŌN

[AKABBĀR 24
Wherever I was, I observed what she was up to: "So-and-so, get lost! - Look, here comes So-and-so!" For she was constantly changing her lovers. What can I say? I'll not be made a laughing stock

I asked her: «By God, look here. What do you see?» She gazed at [my] palm and said: "GOOD! WHITE FAIRIES! I see you [white] as cotton. This glory [IS] UNENDING.»

20 Romance words, following established practice, are printed in capitals.

21 For hummär ('dérision'), see Dozy, R., Supplément, vol. II, 404a.

22 This word is emended from MS nwn. While the rhyme requires $-\bar{u} n$, there is a small problem in the use of an apocopated bōn for 'bueno' when it does not precede a noun. However, Mozarabic may have been like Catalan in dropping word-final - $o$, although the evidence for this is inconclusive, since examples both of retention as well as loss of word-final - $o$ are documented. See Galmés de Fuentes, A., Dialectología mozárabe, Madrid: 1983, 71-73, 136-140, 168-169, 223-224. The form bon, however, appears in 5 Romance harjas, as opposed to only 1 example of bono. See Sola-Sole, J. M., Corpus de poesía mozárabe (las harğa-s andalusíes), Barcelona, 1973, 347, s.v. bwn bon.

23 MS: fátíši l-bašra is semantically incoherent as well as metrically impossible. It looks like a lectio facilior according to which the Eastern scribe has interpreted the first word as an active participle of a Form I verb (but there is no root F-T-S in Arabic), then read the Romance albaš as the Arabic al-bušrà ('good news'), and finally slapped them together as a construct. In contrast, the phrase fätaš albaš (inspired by Corriente's fätoš albos), has a precise parallel in Juan Ruiz, who uses "fadas alvas vos fadaron" in the sense of 'propitious fairies' $(L B A, 739 c)$. The phrase is the opposite of fadas negras (824d: MS. S). See Libro de buen amor: Edición crítica, ed. J. Corominas, 1967 (Reprint, Madrid, 1973), and Armistead, S. G., and Monroe, J. T., "Albas, Mammas, and Code-Switching in the Kharjas: A Reply to Keith Whinnom", La Corónica 11:2 (Spring, 1983), 174-207, at 196, n. 5 .

24 This line is corrupt in the MS, which reads, with a very hypometric syllable count: 'idā l-jāh nwn 'ukubbär. The bracketed insertions are suggestions to fill out the line as required by the meter. As far as nwn 'ukubbär is concerned, Corriente reads bōn a topär, emending $-n$ to $-b$, which is possible. He would also have us consider a scribal rendering of $-t$ as $-k$, which is conceivable, though not as likely on the scale of probabilities. One might also imagine the last word as representing Romance forms such as ocupar, or $a$ capar, none of which appear to provide a satisfactory meaning. The doubling of the $-b$ remains a problem for the interpretation offered above, depending on one's views of the derivation of the original $-p$ in Mozarabic. Acabar in Castilian is a derivative of cabo (Lat. caput). One would have to assume, on the evidence of this passage, that the Mozarabic cognate was capo (spelled $k a b b u$ in the Arabic script), with retention of the etymological $-p$, and that the derivative verbal form was acapār. For this, there is much evidence in the documentation of variously spelled Mozarabic derivatives of Lat. caput such as capacho, capachon, Capdepera, qapellāneš, qapellāniya, capellar, kapēl, capell, capelles, capellos, cappūç, qapūch, capūch, kapūs, qapūs, etc. See Galmés de Fuentes, Dialectología mozárabe, 350-351. 
12. qult aš al-hịlah innamã dāà [ğ]alā las narà [f]a-d-dunyã [li]-man dāâb malā illā law kān mawlā-nā 'abū l-'alā qālat EŠTE KERIYA EW NOM[N]ĀR 25

13. qult anā kaf yakūn wa-nablug̉ ilayh qälat āha 'adhul wa-sallim 'alayh innamā hu hattà tașîr bayn ỉdayh wa-ġraf al-jāh wa-l-izzi ba-l-qințār

14. qultu 'in kān ḍā l-amri kullu șahịh fa-yașir lak wa-lam taqa' ma š šhịh wa-nuhädỉk bi-kulli šayy-an malih wa-nahalyy]ar-ka wa-rḍa qat wa-hitār

15. naštarī lak gadā banīqat šaqī wa-li-dār-ak faham wa-zayt wa-daqị wa-harüf-an samin wa-hamlayn faliq wa-dajäjah w-arba' [f]aāālis kibār

16. qālat ahsant allah yabārak fik las fi wajh-ak wa-lā narìd natrik mustahiqq ant bi-kulli hayr-[an] yajik allah ya'lam tanāà țūl an-nahār

17. yawm-an āhar nazart anā f-as-safar lam nahalli fi bayti gayr al-ạtar bittu layli wa-tumma qumtu sahar wa-l-mukārīn yaqūmu f-al-asḥằ

18. law lā mā kān hada' -ni 'al-miskinn wa-'atāānī f-az-zulma bag̀l-an hajin wa-halaf li 'alayh bi-kulli yamin annu [ya]mšì kamā tarìd misyār

19. fa-kamā jit [n]at'‘llaq rahlī ‘alayh arta'ad li wa-'ašbakat rijlayh hattà jā șāhịibuh wa-qawwam idayh wa-htalafnā wa-qad mašaw at-tujjār

20. iš yakūn illà zāmil-an maflūj wa-fi șulbu 'uqad bi-ḥăl zanbüj kat-tarā-ha min al-wazag hurrüj 'alà 'ajnās taqūm șigār wa-kibār
I said: "What shall I devise? Prices are high these days I see no one in the world who is prosperous now, Unless it be our lord Abū l-'Alā',." She replied: «JUST THE ONE I WANTED TO NAME!

I asked: «How can I manage to reach him?» She answered: «Thus: Go and greet him; As soon as you stand before him, You'll gather honor and glory by the quintal!n

I said: "If all this turns out to be true, It will be to your benefit, for you have met no miser. I'll give you all sorts of fine things, And let you choose, and choose to your heart's content.

Tomorrow I'll buy you a silk hair-net, Plus coal, oil, and flour for your house, As well as a fat sheep, and two loads of split firewood. Along with a hen and four big chickens.)

She said: «How good of you; God bless you, Not that I want to praise you to your face. You deserve every blessing that comes your way. God knows I praise you all day long!!

Next day, I got ready to travel: I left hardly a trace at home; I went to bed that night, then arose at daybreak For muleteers arise at dawn

If only it had not been for how the wretch tricked me! And gave me, in the dark, a worthless mule; And bound himself by every oath in my favor, That it would travel in whatever manner one wished!

When I went to place my saddle on it, It panicked at me, and its rear legs became entangled, Until its owner came and propped up its forelegs, While we were left behind, as the merchants departed.

It is but a paralytic beast of burden,

With gnarls on its back like a wild olive-tree.

You'd think they arose from its timorous trembling.

They protrude in all sizes: large and small...

${ }^{25}$ Here, the MS reading is relatively clear with the exception of the word nammär, which in Hispano-Romance would have to represent a verb nomnar, without reduplication of the $-m$. This aside, the reconstruction seems unexceptionable. I think, however, that kräy represents an imperfect keriya, where Corriente transcribes the conditional kerriya, but translates with the imperfect queria. 


\section{COMMENTARY}

Leaving aside, for the moment, the poem's initial refrain which, following established convention, I have numbered 0 , the above text contains three well-defined thematic units: (1) and introductory section comprising strophes 1 through 7, in which the poet muses over the doctrine of man's subjection to Fate, in illustration of which, he promises to tell his implied audience a story about how he was once compelled to leave town, but then retracts his promise; (2) a central section, spanning strophes 8 to 16 , in which the poet tells a story different from the one promised earlier, about how a frivolous female neighbor told him his fortune, urging him to seek money from Abū l-'Alā', and (3) a final passage, consisting of strophes 17 to 20 in which the poet tells us how he set out on his journey to the intended patron but was prevented from leaving town by the collapse of the paralytic mule he hired. García Gómez and Corriente have assumed that the poem's end is missing because the poet never actually reaches the patron within its confines, thus leaving the reader with what, at first glance, appears to be an unsatisfactory ending ${ }^{26}$. In so doing, these two scholars have overlooked one arresting clue: in the first section of the poem (which García Gómez considered the "least good"), the poet argues that Fate invariably prevents us from achieving our goals, after which he promises, at length and with attention-getting fanfare, to tell us how he was once compelled to leave town against his will (strophes 2-6). In the last section he tells us precisely the opposite, namely a story about how he was prevented from leaving town when he wished to do so. In other words, our poem moves from an initial promise, to its diametrical opposite. So striking is the contrast, that we are legitimately entitled to ask ourselves whether the abruptness of the poem's ending is not deliberate, rather than the result of an accident in transmission. For or against these two opposite possibilities there can be no definitive paleographic argument, since our manuscript is an unicum ${ }^{27}$.

26 Smith, B. H., Poetic Closure: A Study of How Poems End, Chicago, 1968, does not discuss the problem with which we will be dealing here.

27 It is precisely because paleography can only take us so far in literary studies (a point evidently lost upon some) that other methods and disciplines were devised in the humanities. Indeed, the tools offered by the paleographic school of literary criticism, which are much in vogue today in the study of Andalusī strophic poetry, are of little help in resolving our problem, for which other techniques become necessary. See the comments on literary criticism made by Alan Jones in «Sunbeams from Cucumbers; An Ara- 
Let us first note that the initial refrain, "I guarantee that, even if you were given cucumbers [or: 'a choice'] ${ }^{28}$ / You would not see the travels I have seen", contains an allusion not merely to the fact that cucumbers (hiyār) produce gas which rises and falls within the person who consumes them ${ }^{29}$, but that they were the essential ingredient in certain laxatives well-known to medieval Arabs ${ }^{30}$. Hence the references to travel under the compulsion of Fate, or even by choice (hiyär), that abound in this poem, are given a comic and irreverent dimension by being associated, through punning, with a particularly undignified function of the "material bodily lower stratum" ${ }^{31}$. Since the comic allusion to travel under the influence of a laxative, made in the refrain, will be repeated after every strophe, it will serve to undercut the solemn invocations of

bist's Assessment of the State of Kharja Studies", La Corónica 10:1 (Fall, 1981), 38-53, at 41, 50, n. 11, and my reply in "';Pedir peras al olmo?; On Medieval Arabs and Modern Arabists", La Corónica 10:2 (Spring, 1982), 121-147, at 130-131. For the approach of Richard Hitchcock, see "The Interpretation of Romance Words in Arabic Texts: Theory and Practice», La Corónica 13:2 (Spring, 1985), 243-254, in which that author attempts to reconstruct difficult readings on a purely paleographic basis, without taking into account the literary context provided by the poem, without any solid mastery of the languages involved, and in dark ignorance of metrics. In response to Hitchcock's proposals, see Samuel G. Armistead, «Pet Theories and Paper Tigers: Trouble with the Kharjas», La Corónica 14:1 (Fall, 1985), 55-70, and James T. Monroe, "Wanton Poets and Would-Be Paleographers (Prolegomena to Ibn Quzmān's Zajal No. 10)", La Corónica 16:1 (Fall, 1987), 1-42.

28 Hiyär means both 'cucumbers' and 'choice'. In this context, we must avoid translating exclusively, according to either one or the other alternative, as García Gómez ('choice') and Corriente ('cucumbers') have done, for we are dealing with a deliberate and complex pun, the full significance of which will become apparent below.

29 Corriente, El Cancionero hispanoárabe, 342 n. 2, to Zajal No. 84. See, too, the anecdote on the very painful results of quenching one's thirst with water, after consuming cucumbers with yogurt (mást-khiyár), recounted in Browne, E. G., A Year Amongst the Persians, London, $1950^{3}, 190-194$. Our text, however, suggests travels to be made by the speaker, as a result of eating cucumbers, and not of cucumbers, or the gases they produce, traveling within the speaker.

30 The medieval Arabic translation of Dioscorides says: «When cucumbers are cooked whole, and their juice is expressed and drunk with honey and a small quantity of natron, they loosen the bowels and induce a lively diarrhea" (C. E. Dubler and E. Terés [eds], La 'Materia Medica' de Dioscórides: Transmisión medieval y renacentista, Tetuán, 1952-1957, vol. II, 202, no. 134 [translation mine]). Dioscorides text was translated into Arabic by Isțitfan ibn Basil (Encyclopaedia of Islam ${ }^{2}$, vol. IV, 254-255) and revised by Hunayn ibn Ishāq (808-873), the famous translator of Greek works into Arabic (Encyclopaedia of Islam $^{2}$, vol. III, 578-578). The latter taught medicine in Baghdad and was the personal physician of the Abbasid caliph Al-Mutawakkil (r. 847-851). Greek medicine had been introduced to Andalus as early as the ninth century.

31 See Bakhtin, M., Rabelais and his World, trans. H. Iswolsky, Bloomington, 1984, $368 \mathrm{ff}$. 
Fate contained in the poem, and should alert us to avoid taking what it says too literally, and to seek, instead, a deeper meaning in it.

As is the case with most poems by Ibn Quzmān, this one is also organized according to the principles of ring composition ${ }^{32}$, to facilitate the discussion of which, the translation is offered below, with the poem wrapped around itself so that thematically corresponding strophes face one another on opposite sides of the page:

32 For previous discussions of Ibn Quzmān's poetry in terms of ring composition, see my articles: «Prolegomena to the Study of Ibn Quzmān: The Poet as Jongleur», El Romancero hoy: Historia, comparatismo, bibliografía crítica, ed. S. G. Armistead et al., Madrid, 1979, vol. III, 77-129; “Prolegómenos al estudio de Ibn Quzmān: El poeta como bufón», Nueva Revista de Filología Hispánica 34:2 (1985-1986), 769-799; «Wanton Poets and Would-be Paleographers (Prolegomena to Ibn Quzmān's Zajal No. 10)", La Corónica, 16 (1987), 1-42; «Salmà, el toro abigarrado, la doncella medrosa, Ka'b alAḥbār y el conocimiento del árabe de don Juan Manuel: Prolegómenos al zéjel núm. 142 de Ibn Quzmān", Nueva Revista de Filología Hispánica, 36:2 (1988), 853-879; "The Strip-Tease that was Blamed on Abū Bakr's Naughty Son: Was Father Being Shamed, or was the Poet having Fun? Ibn Quzmān's Zajal No. 133» (in press); "The Zajal within the Zajal: Ibn Quzmān's Zajal No. 20, (forthcoming). 
0. I guarantee that, even if you were given cucumbers,

$\boldsymbol{A}$

A 1. My life has been spent in coming and going; As soon as I fall, you'll see me rise again,

Under compulsion, there is no freedom of [choice.

B 2. If I could have had my way, I would have

Not to move from this city,

Ipreferred

Aut rarely does one get what one wants

3. Do you know why I left this town?

Therein lies a tale! See that you tell it to no one I've changed my mind and forgotten all about it

C 4. If I refused, it would be unmannerly. Do you know what happened; the cause of it all? l'll tell you; you forbid my excuses.

B'5. I don't believe in avoidance after a love-union. end, to tell the truth, God forgive him who makes a promise may be. [breaks it!
Since you have been faithful to me, can I be
[faithless?

6. Spare me this, for we are no longer children; [the past;
[ As long as I live, $\mathrm{I}$ won't mention it in any [tongue, For one must fear disgrace.

A'7. A man may live with no lack of money, [Fate. As you know, one has no power.
It's all downhill, as you can see.

\section{$\boldsymbol{B}$}

D 8. On this point, I had an amazing omen, [neighborhood, Who used to come to my home to care for my

E 9. It was evening, and she had come With a small flute in her hand, and began For little females enjoy doing that sort of

10. Wherever I was, I observed what she was up to "So-and-so, get lost! - Look, here comes [So-and-so!
For she was constantly changing her lovers.
What can I tell you? I'll not be made a [laughing-stock AGAIN!

F 11. I asked her: «By God, look here. What do you She gazed at [my] palm and said: "GOOD! WHITE FAIRIES! I see you [white] as cotton.
Herein lies glory [THAT IS] UNENDING."
H'20. It is but a paralytic beast of burden With gnarls on its back like a wild olive-tree. You'd think they arose from his timorous They protrude in all sizes: large and smally.

I'19. When I went to place my saddle on it It panicked at me, and its rear legs became Until its owner came and propped up its While we were left behind, as the merchants
[departed.

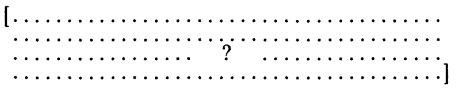

I 18. If only it had not been for how the wretch And gave me, in the dark, a worthless mule; And bound hinself dark, a worth That it would travel in whatever manner one
[wished!

H 17. Next day, I got ready to travel: I left hardly a trace at home;
I went to bed that night then arose at daybreak,
For muleteers arise at dawn.

\section{$\boldsymbol{A}^{\prime}$}

D' 16. She said: «How good of you; God bless you, You deserve every blessing that comes you God knows I praise you all day long! - [way.

E'15. Tomorrow I'll buy you a silk hair-net, Alus coal, oil, and flour for your house, Along with a hen and four big ifirewood. Along with a hen and four big chicken

14. I said: "If all this turns out to be true It will be to your benefit, for you have met no I'll give you all sorts of fine things, And let you choose, and choose to your heart's

F 13. I asked: "How can I manage to reach him?" As answered: "Thus. Go and greet him;

[quintal!n

G 12. I said: "What shall I devise? Prices are high these days; I see no one in the world who is prosperous now,

She replied: "JUST THE ONE I WANTED TO NAME!» 
As mentioned above, the poem is divisible into three distinct thematic units. These have been headed with the boldface capitals A, B, and $\mathbf{A}^{\prime}$, to indicate that the first and last sections stand in a chiastic relationship to one another. Furthermore, within each section, an internal ring pattern also exists. If we examine the first subdivision, we will note that strophes 1 and 7 (i.e., the first and last strophes of A) sententiously proclaim the overall view that human life is controlled by Destiny: «there is no freedom of choice», "one has no power", man lives "under compulsion", "at the whim of Fate». Within this doctrinal framework, the poet adds in 1 "as soon as I fall, you'll see me rise again", thereby portraying an optimistic view of his struggle against the vicissitudes of Fortune. But this view is neutralized by the pessimistic reversal in 7, where it is concluded that man "ends up rising and falling at the whim of Fate». These two border strophes thus circumscribe all human activities by placing them within the control of what medieval Western literature knew as the wheel of Fortune ${ }^{33}$. Yet when we consider the pharmacological implications contained in the refrain, which was intended to be sung at the end of every strophe, the image of the poet rising and falling during his frequent laxative-ordained journeys, offers an entirely different, and highly irreverent dimension to the text.

In strophe 2, the poet sets out to illustrate the general principle previously affirmed, with a specific example taken from his own experience. He tells us that once, when he would have preferred to stay in town, Fate forced him to leave it. This statement is developed in 3 , where the implied reader (or listener) is asked whether he would like to hear the reason why the poet was compelled to depart. Thus the two strophes constitute a sub-unit. In 3, the poet hints that the story he is about to tell is very much worth hearing; he orders the reader not to reveal it to anyone and, now that he has our undivided attention, he changes his mind and decides not to tell it after all, only to conclude that, on second thought, he will tell it (can tell -won't tell- will tell). Strophes 5 and 6 constitute another sub-unit that corresponds to 2 and 3. In 5, the poet

33 The image of the wheel is not commonly associated with Fortune in medieval Arabic literature for the simple reason that the Arabs succeeded in disinventing the wheel used as a means of transportation (when used for irrigation they retained and developed it) and almost eliminating it from those areas under their control. See Bulliet, W., The Camel and the Wheel, Cambridge, 1975. The idea of rising and falling according to the dictates of Fortune, entirely divorced from the Western image of the wheel, as we find to be the case in this poem is, however, very frequent in Arabic poetry. 
argues that his loyalty toward us, his faithful readers, compels him to tell the tale; he has promised to do so, and views the breaking of a promise as a serious sin requiring Divine forgiveness. Since the reader has always remained loyal to the poet, how can the poet possibly not keep faith with the reader? These protestations of unconditional loyalty are followed, in 6, by a less idealistic approach: we are no longer children, and are required to live in a society that adheres to certain moral standards; the past is the past; there is no point in raking up its muck. Therefore, the poet concludes, he will refrain from telling his tale after all, thereby hinting that it is a disgraceful one, and that, if publicized, it would ruin his reputation (can tell -will tell- won't tell). Put differently, the poet, who has dwelt long on the reader's loyalty to him, and announced that such loyalty requires reciprocation on his part, now turns his back on high-minded principle, thus betraying both his faithlessness when under the pressure of possible public censure, as well as his mistrust in the reader's ability to keep his secret. The poet is, therefore, a man lacking in integrity, whose acts are motivated, not by a noble concern for what is intrinsically right, but by a baser desire to save face. Strophe 4, which lies at the very center of section $\mathbf{A}$, adds a further dimension to the poem: the story, with the telling of which the poet is tantalizing the reader, is so good that it might be worth gold. Here, we are to understand that the statements made in the poem are addressed directly to an implied reader, but are being made indirectly, for the benefit of the patron Abū 1-'Alā', from whom payment in gold is expected. In sum, from strophes 2 to 6 the poet has devoted an inordinately long passage to tantalizing the reader with the prospect of hearing a scandalous story that is, ultimately, not forthcoming. On the one hand, the poet argues that all one's intentions are invariably thwarted by Fate. One could then conclude that the poet's intention to tell his tale has been foiled by that same power. But on the other hand, he has devoted exactly six strophes to dwelling on the deliberative process of arriving at a choice not to tell his tale. Was this choice, predetermined by Fate, or was it a cunning ploy on his part to arouse the patron's interest; does the poet's strategy take the form of a sly captatio benevolentiae designed to relieve the patron of that very gold that constitutes the section's central image? Seen from the perspective of this new possibility, the introductory strophes of the poem are hardly "the least good ones", as García Gómez would have it; instead they are an integral component of the poem, insofar as they set the stage for everything that is to follow. 
Section B (strophes 8-16), which constitutes the central part of the poem, also exhibits an internal pattern of ring composition. In strophe 8 , the poet announces that he received an astonishing prediction of his forthcoming good fortune from a female neighbor. He is therefore gullible, if not downright superstitious. In strophe 16, the neighbor thanks the poet for the gifts he has promised her, in the event that her prediction should turn out to be true. While blessing him for his generous intentions to reward her so lavishly, she adds that although she actually praises him all day long before God (e.g. behind his back), she does not wish to praise him to his face. Let us remember that, in Mediterranean societies, one does not generally praise an individual to his face, since this would leave the impression that that individual, or his possessions, are being envied. Such envy would, in turn, inevitably expose the person being praised to the evil eye, which might ultimately bring about his death ${ }^{34}$. Since Islam officially recognizes belief in the evil eye, the neighbor's statement cannot be dismissed as a case of superstition on her part ${ }^{35}$. Nevertheless, by letting the poet know that she constantly praises him behind his back, she automatically cancels the ritual disclaimer she has previously made. In sum, she has told him to his face that she praises him behind his back, thereby neutralizing her prior disclaimer and flattering him to his face, albeit indirectly. As we shall see, the poet had inadvertenly let the cat out of his bag in 12 , by providing the lady with the information she needs in order to reveal to him the "amazing omen" to which he refers in 8 . In 16, its opposite, the lady will let the cat out of her bag intentionally. Whereas the poet, in 8 , betrays that he is gullible and superstitious, the lady, in 16, establishes that she is cunning and unscrupulous. It is clear by now that we are dealing with a fortuneteller who is tricking an unreliable narrator who, in turn, is attempting to trick us.

34 On the evil eye, see: Elworthy, F. T., The Evil Eye: An Account of This Ancient and Widespread Superstition, 1895 (Reprint, New York, 1958); C. Maloney (ed.), The Evil Eye, New York, 1976; Di Stasi, L., Mal Occhio [evil eye]: The Underside of Vision, San Francisco, 1981; Dundes, A., "Wet and Dry, the Evil Eye: An Essay on Indo-European and Semitic Worldview", in Interpreting Folklore, Bloomington, 1980, 93-133; The Evil Eye, Garland Folklore Casebooks 2, New York, 1988; Lykiardopoulos, A., "The Evil Eye: Towards an Exhaustive Studyn, Folklore 92:2 (1981), 221-230.

${ }^{35}$ Islamic belief in the evil eye is based on Qur'än 113:5: "Say: "I take refuge with the Lord of Daybreak... from the evil of an envier when he envies"., See Spooner, B., "The Evil Eye in the Middle East", in Maloney, The Evil Eye, 76-84, at 77-78. Compare Ibn Quzmān, Zajal No. 38:29, where the poet relates the above Qur'ānic passage to his own belief in the evil eye. 
This is so because, in strophes 9 and 10 , which constitute a single sub-unit, the neighbor sashays into the poet's home dancing to the sound of her castanets, with a flute in one hand ${ }^{36}$. Two details pertaining to the lady's portrayal deserve comment: first, since music, in the Islamic tradition, is a work of the Devil, hers is neither an edifying nor a commendable entry ${ }^{37}$; second, for a single person to play a flute (or any other instrument, for that matter) while simultaneously playing the castanets, is physically impossible, inasmuch as it would seem to require at least two, if not more, pairs of hands, and there is no evidence that this lady is a Hindu goddess. Since the presentation of the lady is unreliable, we may, therefore, infer that the poet is attempting to hoodwink us, his readers. The poet then proceeds to tell us that, on many occasions, he has observed the lady faithlessly exchange one lover for another, after which, he boasts that, being a man of the world, and one claiming some experience in matters pertaining to love, he will not be fooled again by women such as his neighbor. This two-strophe sub-unit corresponds to strophes 13 and 14, where the poet, having been hoodwinked in the central section, as we shall soon see, promises the neighbor several picturesque gifts should her clairvoyance prove accurate. In other words, whereas she is presented as a deceiver of men, he shows that, despite his pretentious claims to worldly savoir faire, he has just fallen into her trap. His promised gifts are, nevertheless, conditional on the successful outcome of her prediction, since he states in 14 that he will reward her only «if all this turns out to be true», and not otherwise. Thus the representative of Fate who deceives men is paid in promises, not deeds, by a man who grandly offers her a choice of gifts.

Strophes, 11, 12 and 13 are central to section B. In 11, the gullible poet asks the neighbor to scrutinize his palm. She announces, in a mixture of Arabic and Romance, that he has a bright future ahead of him,

36 The MS reads qusayfah, accepted by Corriente, who thinks it may be a musical instrument, but admits to not being able to identify its precise nature (see El Cancionero hispanoárabe, 343, n. 6). García Gómez emends to qușay'a ('bowl, kettle'), which does not seem to fit with the castanets. However, L. Ibsen Al Faruqi, An Annotated Glossary of Arabic Musical Terms, London, 1981, 259, documents a qas'a ('shallow kettledrum', of which qusay'a would be the diminutive form) used in the Maghrib. This might support García Gómez's emendation. I have emended to qusayba ('small end-blown flute'), which is also documented as a musical instrument in Al Faruqi, 268-269. The precise identity of the word is, therefore, in doubt, but not crucial to the present interpretation.

37 See "Islam and Music", in Farmer, H. G., A History of Arabian Music to the XIIIth Century, London, 1929 (reprint: 1967), 20-38. 
including an unspecified "glory that is unending». In 12 (the exact center of the sub-unit) the poet inquires from whom he is to obtain the glory she so confidently predicts. He adds that times are hard; that no one except a certain Abū l-'Alā' has any money these days, whereupon, with the alertness essential to a successful con artist, the neighbor exclaims that he is "just the one I wanted to name!» The ruse used here is as old as fortunetelling itself. It consists in encouraging the victim to talk about himself, so that he will unsuspectingly provide enough personal information for the fortuneteller to concoct a prediction that will seem clairvoyant. It is, however, a "prediction" after the fact, since the poet has previously and inadvertently revealed the patron's name to the fortuneteller. The poet, who had, earlier on, sworn not to be fooled again by women such as his neighbor (10), has thus naïvely succumbed to her very obvious parlor trick. In 13 , he asks how he can reach the patron, to which the neighbor replies (with an obviousness he mistakes for wisdom and authority) that the best way of doing so is to go to him (!). The poet unquestioningly accepts this answer as the soundest and wisest of advice. She adds that, as soon as he is before the patron, he will "gather glory by the quintal". This is the "unending glory" of strophe 11, which is the twin of 13 . It is not accidental that in 12 , the central strophe of the central section, the name of the patron who, it is hoped, will pour out his gold for the benefit of the indigent poet, is invoked and recorded for posterity. In fact, the centering of a patron's name within a poem is a device often encountered in Andalusi-Arabic praise poetry, particularly in its strophic varieties, while its presence here, lends further validity to our thematic arrangement of the text.

Thus, if in section $\mathbf{A}$ the poet invokes the influence of Fate on man's actions, but then freely chooses to refrain from telling a personal anecdote illustrative of that same influence, possibly as a result of his greed for gold, in B his own actions fall under the total control of one of Fate's more unconvincing and transparent interpreters; a shrewd fortuneteller who is equally disloyal to each of her many lovers and, therefore, unreliable. Likewise, the poet, who both distrusts, and is disloyal to, his faithful readers, begins to acquire the distinct dimensions of an unreliable narrator ${ }^{38}$. It would appear that it is the poet's greed for gold that blinds his eyes to the obvious flaws in the lady's prediction so that,

38 See Riggan, W., Picaros, Madmen, Naïfs, and Clowns: The Unreliable First-Person Narrator, Norman, 1981. 
despite his better judgment, he ends up indulging in a form of wishful thinking that ultimately proves to be his downfall. The poet is, therefore, an unreliable fool, while the thematic core of the poem contains the trick by which he is fooled. Could this ordering of events possibly suggest that the poem as a whole embodies a further trick being played on the reader, yet of which the latter is simultaneously being warned to beware?

The final section of the poem ( $\left.\mathbf{A}^{\prime}\right)$ narrates the poet's failure to leave town in order to reach his patron. In strophe 9, the poet has told us that his encounter with the fortuneteller occurred in the evening ('asiy$y a)$, i.e., the beginning of what we will designate as Day $1{ }^{39}$. In 17 , he adds that on another day (yawm-an ähar), after his encounter with the fortuneteller (which would have begun, at very least, on the evening beginning Day 2), he prepared for his journey, on which he set out at daybreak (sahar) next morning. Since, in 15 (on Day 1) he had promised the lady that "tomorrow (gadā) I'll buy you a silk hair-net", etc., it is clear that he must reach his patron long before the nightfall beginning Day 2, if he is to obtain from him the money with which to make his purchase, which he must proceed to do that very day if he is to keep his promise. Furthermore, one would assume that he is planning to make these purchases back in Córdoba, upon his return, rather than loading his mule, for the return trip, with the picturesque livestock and bundles of firewood he describes in 15. But since mule trains set out at dawn (17), it is not at all clear how he plans to return before Day 3. Either the patron does not live far from town, in which case the requirement of rising early to catch the mule train would seem to be unnecessary, or there is something slightly wrong with the poet's intended chronology. If the latter is the case, then trickery is to be suspected, and this would tie 15 to its twin, 9, in which the lady was represented as simultaneously playing her castanets and flute, all with only two hands. By underscoring the unreliability of the narrator, these two contradictions again warn us to beware of taking this poem at face value. Be that as it may, in strophe 17 , the poet prepares for his journey. In doing so, he tells us that he "left hardly a trace at home", which may be taken to mean that his indigence was so great that, aside from his person, there was not much else

\footnotetext{
39 Note that the Islamic day (yawm) begins at nightfall. It is divided into the daylight hours (nahär) and night-time (layl). In other words, the Arabic words nahär and yawm, which are usually rendered by the English word 'day', are not synonymous. The former is a twelve-, and the latter, a twenty-four hour day.
} 
in the house to take with him, and that, when he left, the latter remained an entirely abandoned encampment ${ }^{40}$. The poet goes to bed (which is an act of reclining), then rises at daybreak. On the one hand, this contrasts with strophe 7, its twin in section A, where we are told that even men with no lack of money rise and fall at the whim of Fate. Here, instead, a man with no money at all goes to bed ('falls') then rises for his journey, of his own volition. On the other hand, 17 contrasts with 20 insofar as reclining and rising represent motion with intent to travel, and are therefore dynamic, whereas 20 is a description of a paralytic mule, and thus static. The mule is compared to a wild olive tree, that is to say, an object so firmly rooted in the ground that, by its very nature, it cannot travel anywhere. Whereas in 17 the poet is indigent to the point that he must travel to improve his lot, in 20 the mule abounds in growths like the gnarls on the trunk of the wild olive, that prevent it from moving. Whereas in 17 the poet rises to go on his journey, the mule cannot rise on its own, and must be propped up, after which it cannot walk. Nor should we neglect the comic aspects of rising and falling under the laxative influence of cucumbers, for if the latter loosen the bowels, olive oil, and that produced by the wild olive tree in particular, induces constipation and is, therefore, an antidote to cucumbers ${ }^{41}$. Strophe 20 also contrasts with 1: in 1, the poet recalls his frequent coming and going; his falling and rising under the compulsion of Fate; in 20 , the paralytic mule is compelled by Fate to remain rooted to one spot and, after having fallen, is unable to rise of its own accord. Instead of moving from one point in space to another, its movements are in the order of trembling, they fail to advance its position. Furthermore, the mule represents Ibn Quzmān's Fate, since it frustrates his attempt to set out on his journey.

Strophe 18 involves the trick played by an unscrupulous muleteer who, in the dark, where it cannot be inspected, rents the gullible poet a paralytic mule. While doing so, the trickster swears that the mule will travel at whatever pace its rider wishes. This passage contrasts, on the one hand, with strophes 5 to 6 , in which the poet promises the reader

40 On the recurring theme of Ibn Quzmān's empty house and larder, compare especially Zajals No. 19:6-8; 68:10.

41 The Arabic translation of Dioscorides assures that olive oil made from unripe olives «is good for the stomach because of the binding properties it possesses, adding "as for the oil of wild olives, it is very constipating" (La 'Materia Medica' de Dioscórides, vol. cit., 35-36 [translation mine]). 
one story about leaving town, but then delivers another about not leaving it. Thus the tricky poet is tricked by the even trickier muleteer. 18 also contrasts with 19, in which the muleteer's promise is broken: he had claimed that the mule would travel at whatever pace one wished when, in fact, it panics, its legs become entangled, it collapses, and must be propped up. In the meantime, the mule train departs, leaving the poet behind. Strophe 19 not only contrasts with 18 , but also with 2 and 3 . In 2 and 3, the poet has told us that, given the choice, he would have preferred to remain in town, and asks the reader if he would like to know why he, the poet, was compelled to leave, whereas in 19 the mule train departs, leaving him in town against his will. Furthermore, in 18, there is another temporal inconsistency, for the poet has told us in 17 that he arose at daybreak (sahar) ${ }^{42}$ adding, in 18, that in the dark ( $z u l-$ $\mathrm{ma}$ ) the muleteer succeeded in assigning a worthless mule to him, presumably because the poet could not see what he was getting. Despite this claim, in 20 , he is perfectly able to distinguish even the small from the large tumors covering the animal's back, which would require light enough by which to see. In fact, having first arisen at daybreak, how is it possible that he subsequently rented a mule in the dark? Once again, the narrator's suspicious chronology betrays his unreliability, thereby warning us to be wary of his claims. Lastly, it should be remembered that a medieval mule train or camel caravan was not quite the same as a modern bus, train, or aeroplane which, once missed, compels the traveler to wait for the next one. There are several passages in Arabic literature where we are informed that a traveler who missed a caravan simply rode forth until he caught up with it ${ }^{43}$. While this might slightly inconvenience the traveler, it is hardly the major disaster Ibn Quzmann makes it out to be. Hence the climax of the poem, which is presented as catastrophic by the speaker in it, is in reality, nothing more than a tempest in a teapot.

The above analysis leaves a blank in the center of section A'. But when we consider the centers of the two previous sections, the reason for this doughnut-hole becomes apparent: in 4, the poet has expressed the wish that the story he did not tell were worth gold. In 12 , the center

42 Strictly speaking, sahar is that time, just before dawn, when there is light, but the sun has not yet risen.

43 This was experienced several times by Ibn Bațtutata. See his Rihla, Beirut, 1964, 15. See, too, the comments on an analogous passage in the maqämät, in J. T. Monroe, The Art of Badi az-Zamān al-Hamadhāni as Picaresque Narrative, 139-140. 
of $\mathbf{B}$, he has singled out the name of the patron from whom that gold is expected. Thus the centers of each of the first two sections contain broad hints for a pecuniary reward. But since the story he finally does tell in A' ends unsatisfactorily, it is not worth any gold (story not told is worth gold - story told is not worth gold). All the same, the purpose of the poem is to extract gold from the patron, and since the latter is not yet forthcoming, there can, as yet, be no reward. Therefore section $\mathbf{A}^{\prime}$ can have no center, and has been left without one by the poet. In sum, the thematic structure of the poem can be outlined with extreme precision, as follows:

\section{$\boldsymbol{A}$}
A 1. Poet Invokes Supremacy of Fate: Poet Falls, then Rises
B 2-3. Poet Plays With Reader: Poet Forced to Leave Town Poet Can Tell - Will Tell Tale
H' 20. Fate Prevents Poet's Travel: Mule Falls, then Cannot Rise I' 19. Fate Plays With Poet: Poet Forced to Stay in Town Mule Cant't Go - Won't Go

\section{4. TALE NOT TOLD: WORTH GOLD}

[TALE TOLD: NOT WORTH GOLD]

B' 5-6. Poet Plays With Reader: Poet Makes False Promise to Reader: Poet Can Tell - Won't Tell Tale

A' 7. Poet Invokes Supremacy of Fate: The Wealthy Rise, then Fall
I 18. Fate Plays With Poet: Muleteer Makes False Promise to Poet: Mule Can't Go - WillGo
H 17. Poet Makes a Choice to Travel: Destitute Poet Reclines, then Rises

$\boldsymbol{B}$

$$
\text { A' }
$$

D 8. Woman Utters False Omen (Poet Accepts It Uncritically)

E 9-10. Woman is Unfaithful to Lovers: He Won't be Fooled by Her D' 16. Woman Utters False Disclaimer: (Poet Accepts It Uncritically)

F 11. Unspecific Prediction of GLORY

E' 14-15. Poet's Reward is Unreliable He Has been Fooled by Her F' 13. Specific Advice to Get GLORY

\section{G 12. SOURCE OF GLORY INVOKED: PATRON IS NAMED BY POET}

Although they tend to cancel each other out, the arguments for and against the doctrine of Predestination nevertheless exhibit an elegant 
patterning in this poem. These arguments may be restated as follows: in section $\mathbf{A}$ the poet first expresses his present conviction that his personal life is governed by Fate (strophe 1), then, going from the particular to the universal in one hasty generalization, he ends by concluding that all men's lives are so governed (strophe 7). In contrast, in section $\mathbf{A}^{\prime}$, he had previously set out on an attempted journey to improve his lot, thereby implying that he did not believe his life to be under the control of Destiny (strophe 17), only to see the mule train's company depart at will, thereby acting as if it too were not under the control of Destiny (strophe 19). These propositions can be charted according to the following logical scheme:

Strophe 7:

A Poet thinks other men are victims of Fate (AFFIRMATIVE-UNIVERSAL)
Strophe 19:

E Poet thought other men were not victims of Fate (NEGATIVE-UNIVERSAL)

\section{FALSE PREDICTION}

Strophe 1:

I Poet thinks he is a victim of Fate (AFFIRMATIVE-PARTICULAR)
Strophe 17:

0 Poet thought he was not a victim of Fate (NEGATIVE-PARTICULAR)

In Zajal No. 84, Ibn Quzmān's arguments for and against Predestination are therefore arranged symmetrically in accordance with the two categories of oppositions (universal-particular, and affirmative-negative), used in Aristotelian logic to distinguish between four basic kinds of statements: (1) affirmative-universal ('all men are mortal'), (2) affirmative-particular ('Socrates is mortal'), (3) negative-universal ('all men are not mortal'), and (4) negative-particular ('Socrates is not mortal'). This classification is what is known to philosophers as the "square of oppositions». Its corners are conventionally designated by the letters A, I, E, $\mathbf{O}$, from the mnemonic words AffI $r m o$ and $n \mathbf{E} g \mathbf{O}$. The first vowel of each word $(\mathbf{A}, \mathbf{E})$ stands for the universal, and the second $(\mathbf{I}, \mathbf{O})$, for the particular ${ }^{44}$.

The figure of Aristotle was the single major influence on medieval Arab philosophy, and the logical framework of his syllogistic, based on the principles of opposition, as expounded in the Categories, was dis-

44 See the explanation in Sanders Peirce, Ch. S., "Memoranda on the Aristotelian Syllogistic", in Collected Papers, vol. II, Cambridge, 1932, section 2.795, 508-517. 
cussed at length by Ibn Quzmān's younger contemporary, the Andalusī philosopher Averroes (1126-1198). For example, we have the following passage from his work:

[Aristotle] said: there are four sorts of opposites-relatives, contraries, privation and state, and affirmative and negative propositions. An example of relation is double and half. An example of contraries is good and evil. An example of privation and state is blindness and sight. An example of affirmative and negative propositions is your saying "Zayd is sitting», «Zayd is not sitting» ${ }^{45}$.

In light of the preceding discussion we might envision our poem as a perfectly balanced logical square of oppositions, of which the four corners are the four propositions we have identified. All the same, its logic is based on a false premise, for in the very center of our square stands the encounter between the poet and his female neighbor, in which she gulls him into believing in a prediction that the text is at some pains to expose as false. After basing his attempt to travel in search of a patron on this false prediction, the poet's expectations have been dashed. From this disappointing experience, he has learned the wrong lesson: that Fate is to blame for all our shortcomings, rather than that we should be more wary of deceitful fortunetellers and muleteers. Contrary to the normal panegyric, in which the poet portrays himself as an equal of the patron, here the poet deliberately presents himself as a fool, and is, therefore, inferior to the patron. But the poem is still didactic, insofar as it aims to teach us, this time by negative example, to reject the speaker's foolish behavior. Or is he such a fool? After all, he has told us in strophe 1 that whenever he is knocked flat by Fate he rises again and, in the final analysis, here we have him still asking for money from the patron he failed to reach on his fictional attempt at doing so.

The reading of the poem I have just offered highlights a set of correspondences so symmetrical in character, that they are unlikely to be the result of mere chance. They are, in my view, a deliberate artifice of the poet. If my reading is not entirely off base, the poem is not missing its end as a result of an accident in the manuscript transmission; ins-

45 Butterworth, Ch. E., Averroes' Middle Commentaries on Aristotle's Categories and De Interpretatione, Princeton, 1983, "Categories», 3.1, 1, parag. 89, p. 73. 
tead, the poet, with malice aforethought, planned his poem to self-destruct.

\section{Conclusions}

In a recent essay on the characteristics of medieval Spanish literary composition, Colbert I. Nepaulsingh considers a number of authors, including Plato, Dante, Virgil, and Juan Rodríguez del Padrón, who have made various usages of the image of the $Y$ of Pythagoras ${ }^{46}$. According to Nepaulsingh, «a person comes to a point in life, a juncture at which three distinct roads may be discerned: the road along which the person has been traveling, a road that leads to a bad end, and a third road that leads to a good end; thus the three roads can be represented graphically by the letter $Y_{11}{ }^{47}$. It is even more remarkable that such works sometimes provide clues to how they should be read, by alluding directly to the $Y$ of Pythagoras ${ }^{48}$. In discussing Rodríguez del Padrón's Siervo libre de amor, Nepaulsingh argues that: «It seems by no means accidental that Juan Rodríguez puts both the narrator and readers of his masterpiece at the same critical juncture-the Pythagorean Y. Readers must judge for themselves whether the book is complete, or almost complete though not really incomplete, or incomplete because part has been lost or because the author did not accomplish his plans for whatever reason" 49 . In Siervo libre de amor, the theme of the wheel of Fortune is closely associated to that of the $Y$ of Pythagoras by means of allusions to the story of Ixion that are imbedded in the text ${ }^{50}$. It would appear, therefore, that incompleteness, fortune, and a choice to be made by the reader, are three basic elements in a broad range of important medieval literary works that, in the West, make use of the $Y$ of Pythagoras and the tale of Ixion to alert the reader to the fact that he is expected to complete the work for himself. Naturally, we cannot expect an Arab poet, who wrote in the Arabic script, to have been aware of symbolism locked into the Greek alphabet, just as we cannot expect him to be aware of the symbo-

\footnotetext{
46 "The Magic Wheel of Fortune", in Nepaulsingh, Towards a History of Literary Composition in Medieval Spain, Toronto, 1986, 160-200.

47 Ibid., 164-165.

48 Ibid., 166-167.

49 Ibid., 167.

50 Ibid., 166.
} 
lism of the wheel of Fortune. All the same, there is some food for comparative thought in the likelihood that, as was the case of certain Western authors, our Arab poet also toyed with the literary possibilities offered by the unfinished poem, although he did so in the terms provided by his own culture. What was his purpose?

Were we, as medieval Arabs, to read Zajal No. 84 on a primary level, we would be amused by its uncouth colloquial diction, plentifully sprinkled, around the center of the poem, with Romance words realistically put in the mouth of a woman of the people ${ }^{51}$. The non-classical diction would, in fact, frustrate any normal linguistic expectations we might have entertained of the panegyrical genre, and encourage us to dismiss the poem as a low-mimetic attempt at the comic. We would also titter at the scatological double entendre suggested by the refrain, and guffaw at the grotesque catalogue of gifts, including the sheep, firewood, chickens, and oil listed in strophe 15 , none of which are images that satisfy the requirements of decorum demanded by Classical Arabic poetry. Finally, we would be struck by the fact that the poem seems to end abruptly and disappointingly, before telling us the scandalous tale it has tantalized us into desiring so eagerly to hear. From all this, we might conclude that the end of the poem must be missing. This unsatisfactory

51 In discussing the genealogies of the Andalusian branch of the Arab tribe of the Banū Balī, Ibn Hazm (993-1064) writes: «The home of the [Banū] Balī in Andalus is the place known by their name, north of Córdoba. They still dwell there today, [organized] according to their kinships, and are unable to speak Romance [al-latiniyya], so that even their women, as well as their men, speak only Arabic" (Jamharat Ansāb al-'Arab, ed. 'Abd al-Salām Muhamammad Hārūn, Cairo, 1962, 443 [my translation]). This passage was discussed by Julián Ribera, in "El cancionero de Abencuzmán», Disertaciones y opúsculos, Madrid, 1928, vol. I, 3-92, at 34 and, more recently, by Coope, J., in Muslim-Christian Relations in Ninth-Century Córdoba, Unpublished University of California $\mathrm{Ph} . \mathrm{D}$. Dissertation in History, 1988, 137-138. Coope comments: «Ibn Hazm writes about one ninth-century Arab clan settled near Córdoba which had maintained its traditions since the conquest so carefully that none of its members spoke anything but Arabic, but he seems to regard this clan as a special case. He makes a point of the fact that even the women spoke Arabic, which must indeed have been an unusual state of affairs.» The above is one good reason, among several ignored by Alan Jones, why «the disproportionately high number of Romance kharjas introduced by the third person feminine singular is very striking... and must in some way be significant» ("Cucumbers", 40). Jones goes on to claim that the reason for this significance cannot be determined on the basis of the available evidence. It seems appropriate to recall, however, that in Andalus most women did not speak Arabic, but only Romance, during the formative years of the muwaššaha, as Ibn Hazm's text makes explicit, and the fortuneteller passage in Ibn Quzmān only confirms. It would thus seem to be the case that Jones is not conversant with evidence that has been widely available since 1928 , and that has been discussed as recently as 1988 . 
conclusion might, on the other hand, leave us with such a sense of frustration that we would feel it necesary to go over the text once more, in order to understand what we have missed in it.

Assuming that we were Muslim intellectuals familiar with theological discourse, were we to embark upon a second reading of the poem, it would be difficult for us not to be struck by the high proportion of references to Predestination and Free Will embedded in the text. We might, therefore, ask ourselves whether the poem is not some sort of investigation into those two doctrines, and attempt to subject the text to allegorical interpretation according to procedures familiar to Islamic theologians. If we were Ašarite theologians and, as such, espoused the doctrine of Predestination, we might remark that, at the beginning of the poem, Ibn Quzmān promised to tell a story about leaving town, but failed to do so, following which he made a decision to leave town, but was frustrated by Fate in his attempt. From this impasse, we might be only too happy to conclude that the poem is an illustration of the supremacy of Destiny over the affairs of men, and to declare Ibn Quzmān an orthodox Sunni. But in so doing, we would have to gloss over the fact that the poet, after lengthy deliberation in the first part of the poem, actually made a distinct choice to retract his initial promise to tell his story, since this detail constitutes a fly in the ointment of our system. However, if we were Mu'tazilite theologians and, as such, believed in Free Will, we might make much of the fact that, in the first section of the poem, when Ibn Quzmān promises to tell his tale, he subsequently decides, on the basis of free choice, not to tell it after all. We might also stress that the prediction made by the fortuneteller is hardly a prediction, but merely a parlor trick. But we would have to gloss over the last section of the poem, in which Ib Quzmān's stated intention to travel is frustrated by a Fate that, although clad in undignified, mulish garb, is unmistakable in its adverse effects. Thus, as long as we were not too rigorous, our interpretation could both illustrate and support the doctrine of Free Will. Consequently, we might wish to consider the poem's author a member of the Shì ite confession, thereby making him a heterodox within the spiritual context of Andalus 52 .

Were we to be impartial, however, we would be forced to admit that the first part of the poem, in which a choice is made and imple-

52 On this subject, see Fierro Bello, M. I., La heterodoxia en al-Andalus durante el periodo omeya, Madrid, 1987. 
mented, cancels out its second part, in which a choice is made but frustrated. Inevitably, the two interpretations I have provided, based on logical criteria, lead to an impasse from which the tools of logic provide no escape. All the same, had we been trained in the theological profession, we might wish to carry our reasoning one step further. In such a case, we might note that Islamic theologians reached a point in their discussions where they made a distinction between acts depending upon the individual's inner volition, and external events that befall him, yet over which he has no control ${ }^{53}$. In light of this distinction, we might proceed to note that, in the first part of the poem, when the poet chooses not to tell the tale he has previously promised us, his choice falls within the category of acts of volition, whereas in the final section, when the poet makes a decision to go on a journey, but is prevented from doing so by the paralytic mule palmed off on him, his failure to depart is the result of something that befell him, over which he had no control. Therefore, in the Mu'tazilite view, in the first instance Free Will prevails, whereas in the second, Predestination is in control. We could, however, turn this argument on its head by claiming that Ibn Quzmān was cheated as a result of his own negligence, this being a distinct possibility that can be supported, textually, on the grounds that it was light enough for him to see, hence he should have been more wary in renting his mule. From the Ašarite perspective, however, both situations are predetermined, for even acts of volition are willed only because God wills us to will them. By this stage in our theological examination of the poem, we would be no closer to a consensus than we were at the outset, because all our conclusions would be based, not on what was said in the poem, but on the conception of God to which we have adhered, and from the perspective of which we are interpreting the poem. Theology, Ibn Quzmān appears to be saying, has led us into the quagmire of an infinite regression; it cannot solve our literary problem because, with God as a wild card in our game, the possibilities are endless.

Assuming that we have perceived the flaws in our previous reading, and that we are dissatisfied with it, we might perforce abandon theological argumentation, since it has gotten us nowhere, and attempt to read the poem as the literary artifact that it is. Here, let us pause to meditate on the circumstance that we are dealing with the specific genre of pa-

53 Discussed in J. T. Monroe, "The Divine Paradox», The Art of Badi az-Zamān alHamadhäni, 47-63. 
negyric. At this stage in our exploration of the text, we might recall that in Classical Arabic praise poetry, the encomiast enjoys a conventional relationship with his patron, in which the patron is expected to reward the praise provided by the poet. But this puts the poet in a vulnerable position, insofar as it risks turning him into a salaried dependant, thereby encouraging the dubious activities of the sycophant, who is prepared to sell his praise to the highest bidder, over those of the incorruptibly honest poet who, like Imru' al-Qays, utters only what he thinks is true. As we return, then, to the problem of sincerity, let us note that panegyrists suffer from as great a credibility-gap as satirists ${ }^{54}$. This situation may have been tolerable in the glorious caliphal days of yore, when honest poets praised sovereigns wrapped in the awesome mantle of religious legitimacy and authority who, therefore, richly deserved all the praise they could muster ${ }^{55}$. It is no longer acceptable in the lackluster Almoravid present, when the poet is being called upon to extol the accomplishments of ordinary men, often his peers, with whose shortcomings he is all too familiar. Given such a situation, Ibn Quzmān has invented a new genre of anti-panegyric that refrains from all forms of praise while, at the same time, it tantalizes the patron by ultimately withholding from him the amusement it at first promises to offer him. Pursuing this line of reasoning, we might imagine Ibn Quzmān saying to his patron: "You and I are locked, by hidebound literary conventions, into an absurd relationship with which neither of us can be comfortable; you, because you have no way of telling when the praise that poets lavish upon you is sincere, although you surely suspect that it is not sincere, and I, because the very nature of this relationship puts me in the awkward position of having to play the flatterer and the mountebank. In this poem, I therefore intend to violate those conventions by neither praising you nor entertaining you. Yet I shall not do all this within the medium of the panegyrical genre. It is up to you, in turn, to reward me for my non-efforts as you see fit. But if you do reward me, you will be wasting your money on a panegyric that, unlike a mule that cannot travel, is a poem that will not praise you. In it, I make my claim to earn, with a poem that has no end, a glory that is de non akabbär, thus demonstrating my superiority over you, who are, by implication, more stu-

54 On the satirist's credibility-problem, see Highet, G., The Anatomy of Satire, Princeton, 1962, 236; Anderson, W. S., Essays on Roman Satire, Princeton, 1982.

55 In the poetry of Ibn Quzmān, the reign of the Abbasid caliph Hārūn al-Rašĩd (786-809) represents such a Golden Age. See Zajal No. 50:4. 
pid than my mule, if you fail to get the point. Furthermore, when intellectual superiors, rather than equals, panegyrize their inferiors, a delicate balance is disrupted, and this is a symptom that the genre is no longer viable in present circumstances.»

According to this third level of interpretation, the poem deals with certain difficulties in using traditional genres in situations that are no longer traditional; it deals with the way in which an author has control over his poem, and with the nature of his relationship to a patron. It is thus a poem about how a former type of poem, suited to a former type of relationship, can no longer be written in present circumstances. Put differently, it is a self-conscious examination of the literary problem involved in composing panegyrics in a non-heroic age. Grosso modo, Ibn Quzmān is doing with the panegyric, what Cervantes was to do several centuries later with the chivalric romances. Moreover, since Islam, like all religions, is a conservative set of beliefs and, as such, may not accept change without undermining the validity of those beliefs themselves, the poet may not express himself through the solemn language, and in the poetic forms, that are identified with the formal culture of Islam. That is one reason why Ibn Quzmān uses colloquial diction and a Romance song-form, deriving (in my opinion) from popular minstrels, in his poetry.

The three levels of interpretation I have attempted to isolate, have not been chosen arbitrarily, for the text itself nudges us, with remarkable insistence, to try our hand at uncovering them. These three levels also happen to correspond to three levels of scriptural interpretation commonly known to the Arabs, both East and West. They were given their most finished form of expression by Averroes in his work entitled Kitāb Faṣl al-maqāl wa-taqrīr mā bayn aš-šarīa wa-l-hikma min al-ittișāl ("The Book of Decisive Discourse Determining the Connection Between Religion and Philosophy"), written ca $1179^{56}$, that is to say, only two decades after Ibn Quzmān's death. On this subject, George F. Hourani says:

The classification of types of reasoning in Aristotle's Organon was well known to the Muslim philosophers. The three types that are relevant are: (1) demonstrative reasoning, based on certain premisses, (2) dialectical

56 See Ibn Rušd (Averroes), Kitāb Faṣl al-maqāl... Arabic Text, ed. G. F. Hourani, Leiden, 1959; Averroes, On the Harmony of Religion and Philosophy, trans. G. F. Hourani, «E. J. Gibb Memorial» Series, London, 1961, New Series, vol. XXI. 
reasoning, based on opinions that are generally accepted and seem probable to thoughtful people, and (3) rhetorical reasoning, based on opinions that are persuasive to ordinary people but will not stand up to criticism. Adopting this classification, the Muslims went a step further and listed the corresponding types of mind, according to their ability to understand and willingness to accept the types of reasoning. Thus a demonstrative man [a philosopher] understands demonstrative reasoning and fully accepts no other; a dialectical man [a theologian] cannot understand demonstrative science (e.g. metaphysics), but is satisfied with rhetorical reasoning; while a rhetorical man [an unsophisticated believer] cannot understand [dialectical] ${ }^{57}$ science and is satisfied with rhetorical reasoning ${ }^{58}$.

The theory of three types of reasoning, corresponding to three hierarchically arranged qualities of mind, as defined by Averroes, was certainly known to Arab philosophers long before him. It is, in fact, implicit in the philosophical allegory Hayy Ibn Yaqzān ('Alive Son of Awake') written by his older contemporary, Ibn Tufayl (ca 11051185) ${ }^{59}$. While Ibn Quzmān knew Averroes personally, and even dedicated a panegyric to him (Zajal No. 106), he did so when the philosopher was still young, and may not yet have developed the theory for which he came to be known. Indeed, as we have mentioned earlier, Averroes did not publish it until two decades after the poet's death, although he must certainly have been aware of it long before then. All the same, the theory was very much alive in Ibn Quzmān's age; that poet was well aware of the major philosophers of his time for, in Zajal No. 20: 26, he mentions Ibn Bājja (d. 1138), who was «the first Andalusī to make direct use of the works of Plato and Aristotle» ${ }^{60}$. What we have mentioned suggests that Ibn Quzmān has constructed his poem with three types of reader in mind, each one of which is intellectually able to arrive at results superior to those reached by the previous, according to

57 The original reads "demonstrative», which must be in error, and which I have emended, above.

58 Ibid, 33.

59 Trans. Goodman, L. E., Ibn Tufayl's Hayy Ibn Yaqzān, Los Angeles, 1983.

60 Averroes, On the Harmony of Religion and Philosophy, 8. Hourani adds: "Ibn Tufayl, passed most of his life under the Almoravid dynasty [1091-1145], though his surviving philosophical work, Hayy Ibn Yaqzän, belongs to the Almohad period [11451230]. Moreover, there must have been some good teachers of philosophy at Córdoba, for the distinguished philosophers of the next generation, Ibn Rushd [= Averroes] and Mọshe Ben Maymūn (Maimonides) [1135-1205], received their education there in the last years of the Almoravides" (ibid., 9). 
a hierarchical system of thought espoused by the Arab philosophers of his age. This consideration suggests that, far from being a bumbling idiot who resorted to writing colloquial poetry using a lowly, local, minstrel form of verse reserved for singing, because he was incapable of expressing himself in a more elevated and respectable medium, our poet was a highly educated man, keenly aware of some of the major philosophical issues of his day, who felt a need to conceal the deeper implications of his work from the eyes of the ignorant reader, at the same time that he was aiming his message at an élite.

What was this message? By this point it should be obvious that the relationships between the poet's persona, on the one hand, and his fortuneteller, muleteer, and implied reader, on the other, are hollow ones based on deceit, disloyalty, and greed. When, as a result of his foolish actions, the persona's aims are frustrated, he comes to the wrong conclusion that Fate, rather than himself, is responsible for his failures. But, insofar as the reader is simultaneously being manoeuvred into a critical vantage point from which he is encouraged to reject the wrong lesson learned by the speaker in the poem, the existence of a right lesson is tacitly implied. We are thus being taught by negative example. While the anti-panegyric of Ibn Quzmān remains didactic in its function, the strategies adopted to convey its message are now indirect and based on irony. They are, thus, closely analogous to those employed in picaresque literature. On a secondary level, the poet sails through dangerous waters when he presents Predestination and Free Will as two doctrines that cancel each other out, the truth about which is, therefore, unknowable. He seems to be saying not only that the rational discussions of the theologians are an ineffective guide to human conduct, but that the theologians themselves are incapable of arriving at any valid form of knowledge. Finally, by portraying the relationship between poet and patron as hollow, Ibn Quzmān is exposing the ineffectiveness, in current circumstances, of a major genre of Arabic literature, and this implies a critique of contemporary society. His stance is therefore a critical one; it is critical of several classes of society, including the common people, the guardians of religion, and the Andalusi notables of his time. In this sense, by exposing society's shortcomings, it stimulates men toward virtue.

To conclude this discussion of a unique poetic salad made up of cucumbers, wild olives, and Predestination, all tossed together with a dressing of Averroism, let me plead that, instead of rushing headlong to 
declare Zajal No. 84 an unfinished poem, it would be more prudent, in the spirit of Ibn Quzmān himself, to leave our remarks open-ended and unfinished. We are, after all, discussing poetry, not merely paleography, or even philology, crucial though the latter two disciplines may be to our discussion.

\section{VERSE ADAPTATION}

Not even fed cucumbers, I'll guarantee,

Will you endure ever, more journeys than me.

In coming and going my life is all spent.

As soon as I halt, on my way I am sent.

Whatever I wish for, is not for me meant.

When under compulsion, one's choice is not free.

I would have preferred, if I'd had my own way,

To stay in this town where I wanted to stay.

One rarely obtains what one seeks, I must say.

Against my desires did my fate thus decree.

You know why I had to depart from this land?

Therein lies a tale! Spread it not, I demand!

What happened, I later forgot and let stand.

To tell you this story I will, though, agree.

Ill-mannered I'd be if I kept it from you,

Although it's worth much in good gold revenue.

You'll learn what transpired, and the cause of it too,

I'll make no excuses; you'll hear it fully.

I hold that avoidance should not follow love,

And never has justice been faulted, above.

If you break a promise, God pardon you, guv.

Since you have been faithful, no treason's in me.

Forget all such nonsense: we're no longer young.

Let bygones be bygones: the past is now done.

As long as I've lived, I have silenced my tongue.

Disgrace must one fear, and disgrace must one flee.

Observe: there are some who lack nothing for wealth,

While others endure both relapse and good health.

We've not, as you know, much control, despite stealth,

For everything slides down the slope, plain to see. 
$A Q$, XVII, 1996 THE UNDERSIDE OF ARABIC PANEGYRIC

I had an experience: its omen was good;

To me did the strangest thing happen that could:

Nearby lived a woman, in my neighborhood,

Who often would come by my house privily.

One time, it was evening when she had arrived,

A flute in her hand, and then she contrived,

Some castanets swiftly to play as she jived,

For gals of that sort do such things readily.

Wherever I stood, I could see what she did:

As one lover left, in her house the next hid.

She changed each new beau; of the old one got rid.

Yet what can I say? That life's over for me!

I asked her to tell what my future might bring. She looked at my palm; said: "An excellent thing: Your fortune is bright, white as cotton, shining.

Behold, you'll have glory unending, carefree!»

Said I: «In such misery, what should I do?

Today, there's no prosperous man to pursue,

Except for our lord Abū l-'Alà, it's true.»

"Precisely the man I'd have named", answered she.

I asked: "How to reach him, and will I succeed?»

She answered: «Indeed, go and greet him with speed.

As soon as you're present before him, proceed,

And quintals of glory you'll reap instantly.»

I answered: "If what you predict should occur, Then, since I'm no miser, rewards I'll proffer;

Yes, bounties aplenty on you I'll confer.

I'll specify, so you'll rejoice in your fee.

Tomorrow, I'll buy for your hair a silk net;

And staples like coal, oil, and flour, you will get;

Of firewood, two loads; a fat ram I'll add yet;

A hen plus four chickens, all large, yours will be.»

She answered: «How kind of you! Bless you, my friend!

No praise, to your face, will I voice -God forfend!

You merit the goodness your fortune might send.

God knows, all day long, you I laud glowingly!»

Thereafter, I packed to prepare for my trip:

Scant traces I left of my home's ownership.

I slept; then at daybreak, I rose for to skip,

Since mule-drivers wake with first-dawn's radiancy. 
A scoundrel, however, did cheat me, alas! 'Twas dark, and he slipped me a very vile ass.

He swore many oaths that the beast was first-class:

"He'll travel», he said, "as you wish, steadily!"

But when I attempted to saddle his back,

He trembled and shook, while his legs twitched, alack!

The owner returned then, to calm the poor hack.

The merchant-train left, and abandoned were we!

That mule's paralytic; a fine piece of junk,

With gnarls on his back like a wild-olive trunk;

They crop out all over his rear; he lacks spunk:

All sizes are they; big and small you can see!

\begin{abstract}
Ibn Quzmān's "Zajal No. 84» has hitherto been viewed as a poem lacking its final, panegyrical section, due to an assumed accident in the manuscript's transmission. According to such a view, the poem has come down to us in an incomplete form.

By analyzing certain prominent thematic features contained in the poem, and showing that they fit closely together, exhibiting a complex but carefully organized structure of the kind known as ring-composition, the following article attempts to suggest that there are strong reasons why "Zajal No. 84» may not be incomplete, but that it may, instead, have been composed with the deliberate omission of the ending one would normally expect in an Arabic panegyric This strategy may have been adopted by the poet, the article proceeds to suggest, in order to stimulate the reader/listener to consider deeper theological, philosophical, and moral implications in a work that, on the surface, deceptively appears to be nothing more than an exercise in buffoonery, devoid of any social concerns. Ultimately, the article attemps to explore the literary value of the poem, and the extraordinary merits of its author.
\end{abstract}

\title{
RESUMEN
}

El zéjel n. ${ }^{\circ} 84$ de Ibn Quzmān se ha considerado hasta ahora como un poema inacabado, al que le falta la sección final de panegírico, debido a un supuesto accidente en la transmisión del manuscrito. Según esta teoría, el poema ha llegado incompleto a nuestros días.

Este artículo, a través del análisis de algunas de sus características temáticas sobresalientes, estrechamente relacionadas y que muestran una estructura compleja y cuidadosamente organizada, pretende mostrar que existen fuertes 
razones para sugerir que el zéjel n. ${ }^{\circ} 84$ no está incabado, sino que se compuso omitiendo, de forma deliberada, la parte final que se espera encontrar usualmente en un panegírico árabe. Se sugiere a continuación que este recurso fue adoptado por el poeta para estimular, en el oyente/lector, la aparición de unas consideraciones de tipo teológico, filosófico y moral a través de una obra que, superficialmente, parece ser tan sólo de carácter bufonesco y sin preocupación social alguna. Finalmente, el artículo intenta explorar el valor literario del poema y el extraordinario mérito de su autor. 